\title{
Protection of Children's Rights in the Icelandic Constitution
}

\author{
Hrefna Friðriksdóttir
}

\section{Introduction}

Iceland's current Constitution dates back to 1944 when Iceland became a separate republic. Since then, Iceland has been actively working towards acknowledging and safeguarding human rights on international, regional and domestic levels. An important step in this direction was the incorporation of the European Convention on Human Rights (EC HR) into domestic law in 1994. In 1995, the Constitution's chapter on human rights was revised with the aim of ensuring conformity with established international obligations. The Constitutional Act No 97/1995 added a range of new provisions, among them, a special substantive provision on children, section 76 subsection 3 , obligating the legislator to guarantee children the protection and care necessary for their well-being. The preparatory works made a special reference to the UN Convention on the Rights of the Child (CRC) among other human rights instruments. The CRC had been ratified in 1992 and was then incorporated into domestic law in 2013.

The aim of this chapter is to give an overview of how and to what extent children's rights are protected in Icelandic constitutional law. It will take a closer look at the origin and expansion of the current Constitution and the developments of constitutional norms and theories of interpretation. The main focus will be on some key provisions important to children's rights and, in this respect, particular weight will be given to an analysis of section 76 , subsection 3. The analysis is based on a critical child-law perspective identifying some of the tensions existing between constitutional law, policies and practice. ${ }^{1}$ The

1 The critical perspective has been defined as an 'on-going exercise of questioning assumptions, knowledge and acts as well as the associated norms and values that shape the social, educational or legal practices that rely on the children's rights framework', Didier Reynaert and others, 'Introduction: A critical approach to children's rights' in Wouter Vandenhole and others (eds), Routledge International Handbook on Children's Rights Studies (Routledge 2015) 10. 
chapter will remark on proposed amendments to the Constitution and finally provide a brief conclusion.

\section{The Icelandic Constitution}

\subsection{Historical Overview}

The decades surrounding the turn of the twentieth century are marked by Iceland's campaign for independence from Denmark. Iceland refused to acknowledge the Danish Constitution adopted in 1849 and, in 1874, Denmark presented Iceland with a separate Constitution concerning the special affairs of Iceland. From 1874 Iceland was a constitutional monarchy under the King of Denmark. ${ }^{2}$ The Constitution was amended in 1904, establishing home rule and an Icelandic government. In 1918, Iceland was granted sovereignty and, in 1944, Iceland finally broke off the union with Denmark and established a separate republic. At the same time, Iceland adopted The Constitution of the Republic of Iceland, which is still in force with later amendments. ${ }^{3}$

Although this was a new Constitution, only minimal amendments were made to the older constitution at this time with the prospects of conducting a more comprehensive revision at a later date. Some parts of the Icelandic constitution have remained more or less unchanged from the time that Iceland was under Danish rule. This has allowed for the recognition of certain constitutional customs and norms or fundamental principles outside the constitutional text. ${ }^{4}$

Some important amendments have been made, most important is the extended revision of the chapter on human rights from 1995, by Constitutional Act No 97/1995. At that time a number of new human rights provisions were adopted, among them a substantive provision for children. The declared intention of the constitutional reform in 1995 was to adapt to international instruments, such as the European Convention on Human Rights and many of the

2 Markku Suksi, 'Common Roots of Nordic Constitutional Law? Some Observations on LegalHistorical Development and Relations between the Constitutional Systems of Five Nordic Countries' in Helle Krunke and Björg Thorarensen (eds), The Nordic Constitutions: A Comparative and Contextual Study (Hart Studies in Comparative Public Law 2018), 30-31.

3 Stjórnarskrá lýðveldsins Î́slands, No 33/1944. Available in english at <https://www.government.is/constitution/ $\geq$ accessed or October 2018.

4 Ragnhildur Helgadóttir, 'Próun stjórnarskrárinnar: Stjórnarskrárbreytingar, venjuréttur og framkvæmd frá 1874 [Changes to the Constitution: Constitutuinal amendmendt, norms and practice since 1874]' in Björg Thorarensen and others (eds), Afmcelisrit Páll Sigurðsson (Codex 2014) 482 . 
UN treaties. According to the preparatory works, the main focus was on civil and political rights. The aim was to incorporate certain important fundamental rights but not to explicitly add and define all constitutional norms. ${ }^{5} \mathrm{It}$ is important to note that it has been argued that the constitutional norm of judicial review has since expanded first and foremost because of the intent to take into consideration the interpretation of well established human rights treaties. ${ }^{6}$

\subsection{International Instruments}

Iceland has actively promoted the protection of human rights on international and European levels. Iceland thus signed and ratified most human rights treaties adopted by the United Nations and the Council of Europe, with no or limited reservations. When it comes to incorporation Iceland adheres to the dualistic approach and only two human rights conventions are part of domestic legislation. The ECHR was directly incorportated into domestic law with Act on the European Convention on Human Rights, ${ }^{7}$ The CRC was ratified in 1992 and incorporated into domestic law in 2013 with Act on the Convention on the Rights of the Child. ${ }^{8}$ Neither of these Acts have constitutional status in Icelandic law.

\subsection{Interpreting the Constitution}

Developments within international human rights jurisprudence have generated a growing interest in the theories of constitutional interpretation. ${ }^{9}$ Constitutional theorists propose different methods of interpretation of constitutional law. It is widely recognised that the written text of the Constitution does not fully represent the extent and depth of constitutional law. The written text is thus supplemented by interpretation and recognition of unwritten constitutional principles. ${ }^{10} \mathrm{~A}$ more predominant question is to what extent societal

$5 \quad$ Parliamentary Assembly 1994-95, Document 389 - case 297.

6 Björg Thorarensen, 'People's contribution to constitutional changes' in Xenophon Contiades and Alkmene Fotiadou (eds), Participatory Constitutional Change: The People as Amenders of the Constitution (Routledge 2017) 106.

$7 \quad$ No 62/1994 (Lög um mannréttindasáttmála Evrópu).

8 No 19/2013 (Lög um samning Sameinuðu pjóðanna um réttindi barnsins).

9 Dóra Guðmundsdóttir, 'Um lögtöku mannréttindasáttmála Evrópu og beitingu í íslenskum rétti [Incorporating and applying the ECHR in Icelandic law]' (1994) Tímarit lögfrceðinga vol 44(3) 154; Guðrún Gauksdóttir, "The effects of ECHR on the Legal and Political Systems of Member States - Iceland' in Robert Blackburn and Jörg Polakiewicz (eds), Fundamental Rights in Europe; The European Convention on Human Rights and its Member States 1950-2000 (OUP 2000). 
developments should influence this development or expansion of constitutional law. Icelandic constitutional scholars generally place an emphasis on the Constitution as a living document, giving due weight to changes in circumstance, knowledge and values in the society.11

Different actors are active in promoting constitutional law in Iceland. The Parliamentary Ombudsman has the objective of monitoring shortcomings in legislation to ensure that the fundamental rights and freedoms of the citizens are not violated in the course of public administration. ${ }^{12}$ The goal of the Ombudsman for Children is to ensure that different stakeholders give full consideration to the interests, needs and rights of children. ${ }^{13}$

Interpretation of the Constitution is also intrinsically linked to the extent to which we recognise the constitutional norm of judicial review of laws and administrative acts. ${ }^{14}$ It is accepted that the democratic, legislative process in a Nordic welfare state actively aims to balance social and individual justice. The preparation and processes rely on open dialogue and collaboration between political and professional stakeholders and the public, actively converging values, social norms and formal laws. The pursuit of individual freedoms is broadly accepted as an organised, institutionalised, consensual activity rooted in the rule of law. It has been argued that in Iceland, as in most of the other Nordic countries, courts favour legislative supremacy and rely to a large extend on the legislative intent and preparatory legislative materials. ${ }^{15}$

In recent decades the classic doctrine of judicial self-restraint has come under challenge. Most significant has been the growing impact of international and regional legislation in strengthening the judicial branch and its role

11 Björg Thorarensen, Stjórnskipunarréttur: Mannréttindi [Constitutional Law: Human Rights] (Codex 2008) 99, 108.

12 The Office of Iceland's Parliamentary Ombudsman was established in 1988 and is today governed by law No 85/1997.

13 The Office of the Ombudsman for Children was established in 1995 and is governed by law No 83/1994. In the Concluding Observations from 2011 the The Committee on the Rights of the Child urged Iceland to consider giving the Ombudsman for Children the competence to handle individual complaints to ensure this mechanism would be effective and accessible to all children, especially to children in vulnerable situations, as well as to ensure this complaints mechanism would be provided with the necessary human, technical and financial resources to ensure its independence and efficacy, see UN Committee on the Rights of the Child, Concluding observations: Iceland (23 January 2012) $\mathrm{CRC} / \mathrm{C} / \mathrm{ISL} / \mathrm{CO} / 3-4$.

14 Ragnhildur Helgadóttir (n 4) 483.

15 Thomas Bull, 'Institutions and Division of Powers' in The Nordic Constitutions: A Comparative and Contextual Study (n 2) 64. 
in interpreting the boundaries of the Constitution. ${ }^{16}$ Constitutional jurisprudence in Iceland can be traced back to the early decades of independence. For many years there were clear signs of judicial restraint. Signs of judicial activism have been more frequent after the amendments to the Constitution in 1995 and in most cases constitutional provisions are applied in conjunction with provisions in the ECHR. It has been argued that Iceland is now one of the Nordic states where judicial review of legislation has been most active. ${ }^{17}$ This development is notable in comparing two cases concerning children. In a case from 1979 the Supreme Court of Iceland on one hand refused to acknowledge contact rights between a child and its father after the breakup of the parents unmarried cohabitation. The court referred to explicit laws and the role of the legislator in changing policy in family matters. ${ }^{18}$ In 2000 the Supreme Court on the other hand relied on the Constitution in acknowledging the standing of a man in a paternity case, contrary to a section in the Children Act explicitly limiting standing to the mother and the child. ${ }^{19}$

Judicial review in Iceland does not address the constitutionality of the legislation itself but instead focuses on the question to what extent constitutional provisions are upheld when a relevant piece of legislation is applied in individual cases. Such cases can only be brought by legal persons with a sufficient interest related to the relevant case..$^{20}$

\section{Children's Rights in Icelandic Constitutional Law}

\subsection{Children's Rights}

Children's rights are most often understood as fundamental claims for the realisation of social justice and human dignity for children. Children are human beings that are thus entitled to all human rights. ${ }^{21}$ The realization of children's

16 Björg Thorarensen, 'Mechanisms for Parliamentary Control of the Executive' in The Nordic Constitutions: A Comparative and Contextual Study (n 2) 68-69.

17 Eivind Smith, 'Judicial Review of Legislation' in The Nordic Constitutions: A Comparative and Contextual Study (n 2) 113.

18 Supreme Court of Iceland, H. 1979:1157.

19 Supreme Court of Iceland, H. 2000:4394. In Supreme Court of Iceland, H. 1999:4723 the court recognised the rights of a woman to contest her maternity as analogous to the right to contest paternity. The decision referred to the right to know one's identity but without mentioning the Constitution.

20 Smith (n 17).

21 Eugeen Verhellen, 'The Convention of the Rights of the Child: Reflections from a historical, social policy and educational perspective' in Wouter Vandenhole and others (eds), Routledge International Handbook on Children's Rights Studies (Routledge 2015) 45-46. 
rights requires the promotion of children as active citizens ensuring them to the maximum extent status, dignity, equality, autonomy, participation, protection and care. Children do not enjoy full political power as sections 34 and 35 of the Constitution sets 18 years as the minimum age for standing and voting in parliamentary elections. Apart from this a child perspective in general demands that children are entitled to the progressive exercise of their rights in accordance with their evolving capacities.

The CRC was the first human rights convention to explicitly emphasise the indivisibility of all human rights, both civil and political and economic, social and cultural rights. The comprehensiveness of the $\mathrm{CRC}$ reflects an interdependence of rights that presents a challenge in integrating policies and practices to ensure meaningful implementation.

It has to be noted that the amendments to the Icelandic Constitution in 1995 do not reflect a comprehensive child perspective. Before analysing the Constitution's special provision for children it is nonetheless important to note other substantive constitutional provisions relating to rights for children and mention some strengths and weaknesses.

\subsection{Some General Constitutional Provisions Important for Children}

The principle of equality evolved through the years in Iceland as one of the more important constitutional norms. ${ }^{22}$ The principle of equality and nondiscrimination is now enshrined in section 65 of the Icelandic Constitution with amendments from 1995. The section states that 'everyone shall be equal before the law and enjoy human rights irrespective of sex, religion, opinion, national origin, race, colour, property, birth or other status'. The principle requires a careful analysis of legitimate differentiation between children and adults in ensuring rights and their enforcement in different contexts. The equality principle is also important to ensure the rights of children in vulnerable positions, for example, young children, adolescents, girls, children with disabilities and children of racial, ethnic or religious minorities. ${ }^{23}$ It has been

22 Parliamentary Assembly 1994-95, Document 389 - case 297.

23 Rachel Hodges and Peter Newell, Implementation Handbook for the Convention on the Rights of the Child (Unicef 2007). The Committee on the Rights of the Child has voiced concerns about the high dropout rate of immigrant children from school and that children of immigrants may not be covered by child health-care services, see Concluding observations: Iceland $\mathrm{CRC} / \mathrm{C} / \mathrm{ISL} / \mathrm{CO} / 3_{-4}$. The Ombudsman for children has expressed concerns for the vulnerability and potential discrimination of the growing number of children seeking international protection in Iceland, Ombudsman for Children, Helstu áhyggjuefni 2017 [Main Concerns 2017], (2017) 32. 
argued that codifying the provision in the Constitution has served to strengthen the protection of vulnerable groups, most often in conjunction with other fundamental rights. ${ }^{24}$ In the concluding observations from 2011 the Committee on the Rights of the Child found it necessary to reiterate earlier observations that had not yet been implemented or sufficiently implemented, most pointedly the lack of a data collection system that is a prerequisite for introducing and applying strategies to address inequalities. The committee voiced concerns that systems of data collection did not cover all areas of the Convention and that there were insufficient mechanisms for the processing, evaluation and assessment of such data. The committee encouraged Iceland to develop a comprehensive system for collecting, processing and analysing data as a basis for assessing progress achieved in the realisation of child rights, disaggregated by age, sex, geographic location, ethnicity and socioeconomic background to facilitate analysis of the situation of different groups of children. ${ }^{25}$ The Ombudsman for Children has especially expressed concerns about geographical inequities and urged the state to research differences in services and ensure all children living in Iceland equal opportunities. ${ }^{26}$ The Government has duly recognised these concerns. ${ }^{27}$

Section 67 of the Constitution protects persons from the deprivation of liberty and can apply to children in certain circumstances. ${ }^{28}$ Cases concerning child protection interventions are though usually scrutinised under section $71 .^{29}$

24 Thorarensen (n 11) 593. As an example in 1999 the Supreme Court of Iceland found that the University of Iceland had failed to provide a blind student with the necessary support to enable her studies, Supreme Court of Iceland H.1999: 39o.

25 Concluding observations: Iceland $\mathrm{CRC} / \mathrm{C} / \mathrm{ISL} / \mathrm{CO} / 3^{-4}$. This is still a legitimate concern, see Iceland's $5^{\text {th }}$ and 6 th periodic report to the Committee on the Rights of the child, November 2018, 11-13, <https://www.stjornarradid.is/lisalib/getfile. aspx?itemid $=576 \mathrm{~b}-$ ca31-3130-11e9-9431-005056bc4d74> accessed 21 August 2019. A bill proposing changes to the Act on the Ombudsman for children was introduced in Parliament on september 2018, obligating the Ombudsman to collect and disseminate necessary disaggregated information on children, Parliamentary Assembly 2018-2019, Document $15^{6}$ - case 156 .

26 Ombudsman for Children, Helstu áhyggjuefni 2017 [Main Concerns 2017] (n 23) 23. See also European Agency for Special Needs and Inclusive Education, Education for All in Iceland - External Audit of the Icelandic System for Inclusive Education (European Agency for Special Needs and Inclusive Education 2017) 17.

27 Iceland's $5^{\text {th }}$ and 6th periodic report (n 25) 18.

28 District Court of North-East Iceland, 31 December 2009, (case No E-228/2009), where a 14-year-old girl was arrested as a passenger in a stolen vehicle and detained for twelve hours at the police station, considered a violation of section 67 of the Constitution.

Thorarensen (n 11) 134-135. 
Section 68 of the Constitution protects persons from torture or any other inhuman or degrading treatment or punishment. ${ }^{30}$ This provision has special importance to children in public care but also refers to positive obligations on the state to ensure adequate protection within the family and in other settings. ${ }^{31}$ In spite of this the Supreme Court of Iceland in 2009 acquitted a stepfather accused on spanking his two stepsons as punishment for alleged bad behaviour. ${ }^{32}$ The judgement was heavily criticised and amendments to legislation ensued ${ }^{33}$ In the concluding observations from 2011 the Committee on the Rights of the Child expressed concerns regarding different types of violence and recommended that Iceland ensures, through adequate legal provisions and regulations, that all children victims and or witnesses of crimes, e.g. children victims of abuse, domestic violence, sexual and economic exploitation, abduction, and trafficking and witnesses of such crimes, including those perpetrated by State and non-State actors, are provided with the protection required by the CRC. ${ }^{34}$

Section 71 of the Constitution ensures freedom from interference with privacy, home and family life. ${ }^{35}$ The right to respect for private and family life has come to encompass a wide range of areas. The right to privacy, home and family thus encompasses, for example, the right to data protection, a person's identity, intimacy and moral and physical integrity, home and familial relationships. ${ }^{36}$ The Supreme Court of Iceland, in 2014, iterated the right to know one's identity as an integral part of the right to privacy and family life in a paternity suit challenging mandatory DNA testing. ${ }^{37}$ To name another example of the different contexts the Supreme Court in 2017 found the refusal to acknowledge non-biological intended parents as legal parents persuant to a surrogacy arrangement not a violation of section $71 .^{38}$

30 This right to protection was recognised as a constitutional norm before the amendments in 1995 .

31 Thorarensen (n 11) 174; 177; Parliamentary Assembly 1994-95, Document 389 case 297 .

32 Supreme Court of Iceland, 22 January 2009, (case No 506/2008).

33 Hrefna Friðriksdóttir, 'Að nota samning SP um réttindi barnsins með hendi og vendi að hingað til brúkanlegum siðvana [Using the CRC with force as hitherto was customary]' in Rannsóknir í félagsvísindum X (Félagsvísindastofnun Háskóla Íslands 2009).

34 Concluding observations: Iceland, $\mathrm{CRC} / \mathrm{C} / \mathrm{ISL} / \mathrm{CO} / 3-4$.

35 The right to privacy was recognised as a constitutional norm before the amendments in 1995. It is worth noting that the right to life and to dignity are not explicitly protected in the Constitution but are recognised as constitutional norms.

36 Thorarensen (n 11) 286, 288, 309, 313 .

37 Supreme Court of Iceland, 28 January 2014 (case No 80o/2013).

38 Supreme Court of Iceland, 30 March 2017 (case No 367/2016). 
Section 71, subsection 3 recognises lawful interference with privacy, home and family life if this is urgently necessary for the protection of the rights of others. Most cases involving the claims of child protection authorities for depriving parents of custody rely on the balancing of the rights of parents and children according to section 71, arguing how the right of the child to stability, harmonious development and protection from harm, aided by a general reference to section 76 , subsection 3 justifies interference with the rights of the parents to the protection of family life. ${ }^{39}$

\section{Special Provision for Children in the Icelandic Constitution}

\subsection{Section 76 of the Constitution}

The amendments to the Constitution from 1995 introduced a new provision specifically tailored to children. Children are the only specific group of people guaranteed special constitutional protection. The provision is situated as a subsection of section 76 on economic and social rights and it is therefore appropriate to look at that section as a whole.

\subsection{Economic and Social Rights}

Section 76 , subsection 1 states that the law shall guarantee for everyone the necessary assistance in case of sickness, invalidity, infirmity by reason of old age, unemployment and similar circumstances. Article 11 of the UN Convention on Economic, Social and Cultural Rights (ICESCR) formulates the right to an adequate standard of living, including adequate food, clothing and housing. It has also been argued that adequate standard of living includes the right to care and health. ${ }^{40}$ The committee on the ICESCR has emphasised three levels of obligations on State parties: the obligation to respect, to protect and to fulfil, the latest incorporating both an obligation to facilitate and to provide. ${ }^{41}$

39 Eg Supreme Court of Iceland, 25 January 2018, (case No 35/2017); Supreme Court of Iceland, 3 November 2016, (case No 466/2016).

40 Kári Hólmar Ragnarsson, 'Dómstólar geta ekki vikið sér undan pví að taka afstöðu: Um vernd efnahagslegra, félagslegra og menningarlegra réttinda fyrir dómstólum' [Courts cannot avoid taking a stand: On the protection of economic, social and cultural rights before the courts]' (2009) 62(4) Úlfljótur tímarit laganema 495, 5 ०4.

41 UN Committee on Economic, social and cultural rights, General Comment No 12: The right to adequate food, 1999. UN Doc. HRI/GEN/1/Rev.7(2004). 
Section 76 is formulated differently from previously mentioned human rights provision as it refers to obligations by the legislator. ${ }^{42}$ For most of the twentieth century constitutional theorists formulated economic and social rights first and foremost as political policy statements and not as individual rights, and before the constitutional amendments in 1995, the Supreme Court of Iceland had never directly applied similar provisions. ${ }^{43}$ This changed gradually and the year 2000 saw a landmark case on the question of justiciability of social rights. ${ }^{44}$ The case involved an administrative regulation that reduced a person's disability pension in relation to spousal income. The court stated that section 76 , subsection 1 obliges the state to ensure a minimum level of support structured on objective grounds. While acknowledging the legislator's margin of appreciation, the court stated that it could not avoid providing judgement on whether the system provided by law respected the minimum rights included in section 76 subsection 1, with a special reference to section 65 on equality. ${ }^{45}$ It is interesting to note that while the court refers to positive obligations of the state, the link to the equality principle de facto only required the court to evaluate to what extent restrictions on benefits to certain persons was discriminatory. It is still debated to what extent courts will feel competent to formulate substantive economic and social rights, or the necessary minimum assistance in different contexts. ${ }^{46}$ It has been argued that later judgements of the

42 Thorarensen (n 11) 536. Other provisions in the human rights chapter address rights and place limitations on interference.

43 Björg Thorarensen, 'Beiting ákvæða um efnahagsleg og félagsleg mannréttindi í stjórnarskrá og alpjóðasamningum [Applying provisions on economic and social rights in the Constitution and international conventions]' (2001) 51(2) Tímarit lögfræðinga 78; Thorarensen (n 11) 538 .

44 Supreme Court of Iceland, H. 2000:4480.

45 See further eg Brynhildur Flóvens, 'The Implementation of the UN Convention and the Development of Economical and Social Rights as Human Rights' in Oddný Mjöll Arnardóttir and Gerard Quinn (eds), UN Convention on the Rights of Persons with Disabilities (Martinus Nijhoff Publishers 2009) 275. Similar arguments were used by the District Court of Reykjavík, 4 July 2018 (case E-2174/2017) in a case concerning special care benefits for children, which found it unlawful to only pay benefits to parents providing special care if the child had been diagnoced after the date of implementation of the rules. The judgement was later set aside by the Supreme Court on procedural grounds, see Supreme Court of Iceland, 12 March 2019 (case No 12/2019).

46 See, eg, Ragnar Aðalsteinsson, 'Stefnumið eða dómhæf réttindi? [Policy or justicability?]' in Ragnheiður Bragadóttir (ed), Afmcelisrit:Jónatan Pórmundsson (Codex 2007) 409-441; Thorarensen, 'Beiting ákvæða um efnahagsleg og félagsleg mannréttindi' (n 43) 99-101; Ragnhildur Helgadóttir, 'Afstaða dómstóla til hlutverks síns við mat á stjórnskipulegu gildi laga - próun síðustu ára [Court's position on constitutional judicial review - recent developments]' (2002) 55(1) Úlfljótur 97-110; Ragnarsson (n 40) 495-593. Ragnarsson points 
Supreme Court on economic and social rights have been much more restrictive and have not lived up to the promises of the landmark case from $2000 .{ }^{47}$

\subsection{The Right to Education}

Section 76 , subsection 2 states that the law shall guarantee for everyone suitable general education and tuition. The principle requires the state to actively implement policies that promote equal opportunities and the potential of all children. Children with special needs are a highly vulnerable group in this respect. In a Supreme Court judgment from 2005 the court refused a mother's claim for costs derived from her daughter having to attend a special school outside her home community. ${ }^{48}$ According to the court, such costs were not considered sufficiently related to providing education but were instead part of the parents' duty to support the child. The judgment has been criticised for not requiring the state to fulfil the duty to ensure suitable education for the child. ${ }^{49}$ The circumstances underlying a Supreme Court judgment from 2015 reveal deficiencies in providing sufficient learning materials in Icelandic sign language in elementary schools. ${ }^{50}$ Concerns have also consistently been raised in general on the implementation of the policy on education for all, or inclusive education. While legislation and policies seem to support the goals and aims of inclusive education, there seems to be a lack of clarity around the concept and how it should be put into practice, evaluated and monitored. The majority of stakeholders across all systems levels believe that current funding mechanisms and the resource allocation framework are not equitable or efficient in any school phase..$^{51}$

out that section 76 subsection 1 would benefit from more clarity as to what rights are protected and how the state should ensure such rights.

47 See, eg, Supreme Court of Iceland, 2017 (case No 464/2017) and Supreme Court of Iceland, 1 December 2016 (case No 80/2016). See Kári Hólmar Ragnarsson, ‘Falsvonir Öryrkjabandalagsdómsins? - nýleg dómaframkvæmd um félagsleg réttindi [False hopes from the Social Security Case? recent judgments on social rights]' (2017)70(1) Úlfljótur 41-86; Kári Hólmar Ragnarsson, 'Mannréttindasamningar og túlkun laga: nýlegir dómar í andstæðar áttir [Human Rights Treaties and the interpretation of law: recent judgments in opposite directions]' <https://ulfljotur.com/2018/05/1 7/mannrettindasamningar-ogtulkun-laga-nylegir-domar-i-andstaedar-attir/> accessed 12 October 2018.

48 Supreme Court of Iceland, $\mathrm{H}_{2}$ 2005:3380.

49 Ragnarson (n 40) 522; Thorarensen (n 11) 556.

50 Supreme Court of Iceland, 12 August 2015, (case No 394/2015). The District Court generally acknowledged the right to inclusive education, but the case was dismissed on procedural grounds.

$51 \quad$ European Agency for Special Needs and Inclusive Education (n 26) 15. 


\subsection{Children's Right to Protection and Care}

Finally, section 76 subsection 3 , states that for children, the law shall guarantee the protection and care that is necessary for their well-being.

According to the preparatory works, this new provision acknowledged international trends in the area of child rights and was inspired by article 3 of the CRC and to a degree by article 24 of the UN Convention on civil and political rights (ICCPR). The preparatory works refer to the provision to some extent as a statement of policy or intent placing the burden on the legislator to pass laws guaranteeing children protection and care. More importantly, the provision was considered providing a material basis for the limitations of other constitutionally protected rights, when necessary in order to protect children. The preparatory works specifically name as an example that section 76 , subsection 3 may be used as an argument to limit freedom of expression in the form of restricting children's access to harmful material. The provision is also considered to provide arguments for limiting freedom from interference with privacy, home and family life. In this respect, the preparatory works emphasise that the welfare of children may demand limits to the rights of parents crucial in the implementation of child protection legislation. ${ }^{52}$

The provision raises several important questions. As mentioned before the provision was inspired by article 3 of the CRC. The preparatory works do not distinguish between the different subsections of article 3. Article 3(1) entails that stakeholders must ascertain the impact on children of their actions in order to ensure that the best interests of children are a primary consideration. ${ }^{53}$ Article $3(2)$ is more in line with section 76 , subsection 3 of the Icelandic Constitution as it obliges states to ensure the child such protection and care as is necessary for his or her wellbeing. Article 3(2) of the CRC has been described as an umbrella provision constituting a comprehensive reference in interpreting the general and overall obligations enshrined in the convention. The terms protection and care must thus be read expansively and the duty to ensure encompasses both passive and active obligations. ${ }^{54}$

The preparatory works do not explain why the special provision for children is part of the section on economic and social rights. As previously mentioned, the preparatory works refer to article 24 of the ICCPR. Article 24 of the ICCPR emphasises the rights of the child to protection and entails the adoption of

52 Parliamentary Assembly 1994-95, Document 389 - case 297.

53 Hodges and Newell (n 23) 35. The Government recognises criticism that has been levelled on the general lack of applying child rights impact assessments, see Iceland's $5^{\text {th }}$ and 6 th periodic report (n 25). 
special measures to protect children, primarily to ensure that all children fully enjoy the other rights enunciated in the ICCPR. ${ }^{55}$ It should be clear that the rights to protection and care, even prima facie, cannot be defined solely as economic and social rights. The right to protection thus includes, for instance, the right to life (ICCPR, article 6), to protection from violence (e.g. ICCPR, article 7) and to liberty (ICCPR, article 9). The preparatory works make no references to the ICESCR in connection with section 76 , subsection 3 , which might have been more appropriate if the idea was only to require progressive realisation of economic, social and cultural rights. The problem with this, albeit indirect, link between children's rights and economic and social rights is mainly twofold. Firstly, it may in practice divert attention away from the necessary holistic analysis on what protection and care, or wellbeing of a child, actually entails. Secondly, economic and social rights are often considered ambiguous or as idealistic manifestos or political policy statements that are less enforceable or suitable for judicial review. ${ }^{56}$

Yet another question largely left unanswered in the preparatory works is what protection and care actually entail and how laws shall ensure the extent necessary for the well-being of children. The preparatory works make little attempt to describe what section 76 , subsection 3 adds to the protection and care that children enjoy according to other sections of the Constitution previously mentioned. It is generally accepted that children have specific vulnerabilities and needs that demand particular responses. The important role of the CRC is to respond to this and the CRC can as a whole serve as an important guideline in enhancing specific rights for children or interpretation of rights from a child rights perspective. ${ }^{57}$ As an example, article 19 of the CRC demands special considerations when ensuring children protection from abuse and neglect. ${ }^{58}$ Another example is article 27 of the CRC, which has a broader scope

55 It is recognised that such measures may also be economic, social and cultural, see UN Committee on Civil and Political Rights, General Comment No 17: Article 24 (Rights of the Child), 1 April 1989.

56 Eg Thorarensen, 'Beiting ákvæða um efnahagsleg og félagsleg mannréttindi' (n 43) 87-88; Jane Fortin, 'Children as Right Holders' in Antonela Invernizzi and Jane Williams (eds), Children and Citizenship (Sage Publications 2008) 57.

57 Nigel Cantwell, 'The Origins, Development and Significance of the United Nations Convention on the Rights of the Child' in Sharon Detrick and others (eds), The United Nations Convention on the Rights of the Child: A Guide to the 'Travaux Préparatoires' (Martinus Nijhoff Publishers 1992) 29.

58 UN Committee on the Rights of the Child, General Comment No 8: The rights of the child to protection from corporal punishment and other cruel or degrading forms of punishment (arts. 19; 28, para.2; and 37, inter alia) (2 March 2007) CRC/C/GC/8, 6: 'The distinct nature of children, their initial dependent and developmental state, their unique human 
than comparable articles in ICESCR in recognising the right of every child to a standard of living adequate for the child's physical, mental, spiritual, moral and social development. Article 28 on education places special obligations on states to provide and protect children during compulsory schooling, and article 31 of the CRC on play, leisure and rest describes conditions necessary to protect the unique and evolving nature of childhood. ${ }^{59}$

Section 76 , subsection 3 does not mention the important right of children to participation. It can be argued that participation is included as a necessary element in the interpretation of protection, care and wellbeing. ${ }^{60}$ It can also be argued that participation has acquired the status of a constitutional norm, as a general principle of the CRC, widely accepted in domestic legislation and court practice and with integral ties to the explicit constitutional provision. ${ }^{61}$

Courts have added very little to the analysis of section 76 , subsection 3 . The provision is regularly cited alongside section 71 in child protection cases without offering specific interpretations. In an interesting case from 2013 a mother's disability pension was reduced in relation to the number of years she had lived in Iceland. According to the claimant, the reduction was unlawful as section 76 , subsection 1 obliged the state to secure her the same minimum assistance as other citizens. The claimant also contended that the reduction of her disability pension directly affected her daughter's welfare and was therefore in violation of section 76 , subsection 3 . Her claims were denied. ${ }^{62}$ As mentioned before, the Supreme Court has formulated that as a general principle the state has to ensure minimum social security. It remains to be seen if, how and to what extent the court would balance or reconcile the principle of the best interests of the child with applying minimum standards in securing care and protection. ${ }^{63}$

potential as well as their vulnerability, all demand the need for more, rather than less, legal and other protection from all forms of violence.'

59 UN Committee on the Rights of the Child, General Comment No 17: The rights of the child to rest, leisure, play, recreational activities, cultural life and the arts (ars. 31 ) (17 April 2013) $\mathrm{CRC} / \mathrm{C} / \mathrm{GC} / 17,4$.

6o See Elisabet Gísladóttir 'A Child's Right to Participation in Iceland' in Trude Haugli and others (eds), Children's Constitutional Rights in the Nordic Countries (Brill 2019). See also Hodges and Newell (n 23) 40-41.

61 Eg Dóra Guðmundsdóttir, 'Stjórnarskrárbundnar meginreglur og stjórnarskrárvarin réttindi [Constitutional norms and constitutional rights]' in Pétur Kr. Hafstein and others (eds), Afmcelisrit Guðrúnar Erlendsdóttur (Hið íslenska bókmenntafélag 2006) 141.

62 Supreme Court of Iceland, 13 June 2013 (case No 61/2013).

63 The case adjudicated by the District Court of Reykjavík 2017 (n 45) did not require the judge to rule on the minimum or necessary amount of benefits to ensure the wellbeing of the child, only on who was eligible to receive benefits already established in legislation. 
It has been argued that the indeterminateness of section 76 , subsection 3 particularly minimises the possibility of active judicial review and that courts would be most likely to react in cases of gross negligence of the state to uphold laws or provide adequate protection in certain contexts. ${ }^{64}$ In contrast the Committee on the Rights of the Child specifically encourages states to ensure that domestic adjudicating bodies are able to give full justiciability to economic, social and cultural rights of children, to ensure the full realization of these rights. ${ }^{65}$

It can be argued that the lack of analysis and guidance in the preparatory works with the amendments to the Constitution is reflected in the volume of criticism on children's economic and social rights in practice. While significant progress may be traced in the passing and reviewing of legislation the allocation of resources for implementation in an effective and sustainable manner seems to be lacking. Of particular concern is the question of reversing extensive budget cuts implemented in the wake of the financial crises in 2008. Iceland does not seem to have responded to the challenge of consistently increasing its investment in social security and on special protection in a substained manner. ${ }^{66}$ Another continuous and growing concern is the difficulties in responding to complex multi-faceted challenges facing children that require co-ordinated action across different sectors. ${ }^{67}$

The criticism was neatly summed up by the Ombudsman for children in 2017 in expressing grave concerns over the lack of services to children:

The Ombudsman is getting used to lofty promises in laws and policies not being reflected in lived realities of children at stake. Many examples can be mentioned where children do not receive the services they are entitled to by law. The Ombudsman for children has grave concerns for the uncertainty and instability that for so long has dominated the field of support and services to children. The Ombudsman has often celebrated plans for better services that have never or only partially been

\footnotetext{
64 Thorarensen (n 11 ) 56 o.

65 UN Committee on the Rights of the Child, Day of General Discussion on 'Resources for the rights of the child - Responsibility of states' 21 September 2007).

66 Iceland's $5^{\text {th }}$ and 6 th periodic report (n 25) $33-34$.

67 Ombudsman for Children, Helstu áhyggjuefni 2017 [Main Concerns 2017] (n 23) 25-26; Draft of Iceland's 5 th and 6th periodic report (n 22) 42-43. See also Árni Páll Árnason, 'Knowledge that works in practice: Strengthening Nordic co-operation in the social field' (Nordic Council of Ministers 2018) 9.
} 
implemented ... Work is abundant when it comes to eradicating the economic and social disparities that children in Iceland face. ${ }^{68}$

It is generally accepted that the Icelandic Constitution is outdated in many respects, but for decades not much effort was made to introduce a comprehensive overall review. The collapse of the banks and the economic crisis in 2008 fuelled a public demand for constitutional reform. A new coalition government came into power in 2009, which prioritised the revision of the Constitution and set in motion an elaborate constitutional project inspired by the idea of direct input from the people having the constituent power. The Parliament passed Act No 90/2010 establishing a consultative Constitutional Assembly that had the task of revising the Constitution. The Assembly was later replaced by a Constitutional Council with the same role. Its proposals were submitted to the Parliament as a bill for a new Constitution of Iceland in 2011. Since then there have been heated debates on almost all aspects of the project, the legitimacy of the Council, priorities, internal cohesion of the draft and the quality and wording of many of the provisions.

The Constitutional Council's proposals included a new human rights chapter drawing inspiration from various international human rights instruments. Among the notable features is a provision strengthening the rights of children. The draft article 12, Rights of Children, reads as follows:

All children shall be assured by law of the protection and care that their welfare demands.

The best interest of the child shall always have priority in decisions regarding their affairs.

A child shall be guaranteed the right to express its opinions in all instances concerning it and due recognition shall be accorded to the child's opinions in concert with its age and maturity. ${ }^{69}$

68 Ombudsman for Children, Helstu áhyggjuefni 2017 [Main Concerns 2017] (n 23). See also the Governments recognition of the issues in Iceland's $5^{\text {th }}$ and 6 th periodic report (n 25) $35^{-} 37,42,43,45,52,54,57^{-5} 8$ and 61.

69 See Stjórnlagaráð, a Constitutional Council, A Proposal for a new Constitution for the Republic of Iceland <http://www.stjornlagarad.is/other_files/stjornlagarad/Frumvarpenska.pdf $\geq$ accessed 1 October 2018. 
The amendments to the Icelandic Constitution in 1995 certainly had the aim to serve as tools of change. The references to international instruments and the acceptance of the Constitution as a living instrument alongside constitutional norms invites the interpretation of constitutional law from a child perspective and should offer the possibilities to ensure progressive holistic implementation.

The special provision on children incorporated in 1995 does symbolise at least a basic recognition of the rights of children. In describing section 76 , subsection 3 mainly as a policy statement placing obligations on the legislator the provision leans more to a protective or welfarist perspective than a child rights perspective. ${ }^{70}$ The preparatory works' lack of a comprehensive analysis and the ambiguous placement of the subsection within section 76 on economic and social rights may account for the fact that the provision seems to have failed to serve as a substantive reference for furthering children's rights.

On one hand, the general wording and lack of further substantive analysis in the preparatory works naturally leads to difficulties in practical application and may be responsible for the fact that the provision does not seem to have had much direct impact on laws, policies or practice. On the other hand, such indeterminate references can offer considerable scope for interpretation. Here, the CRC and the General Comments of the UN Committee on the Rights of the Child can provide important interpretive guidance.

The Government of Iceland has recognised that there has been a consistent lack of a comprehensive holistic official policy on matters concerning children. Such a policy could utilise the special provision in the Constitution as an umbrella encompassing and incorporating the rights of the CRC. ${ }^{71}$

The CRC seems to be the most relevant guiding light in furthering children's rights in Iceland. The incorporation of the CRC has given much more visibility to the rights of the child and helped in developing a stronger child-oriented approach within both public and private sectors. Despite this, the concluding observations of the Committee on the Rights of the Child and numerous domestic reports demonstrate a number of shortcomings when it comes to the realisation of the rights of the child under the CRC. The Government has acknowledged that incorporation in itself is insufficient and that ongoing transformation and adaptation is needed. ${ }^{72}$ It must also be iterated that the

70 See further Philip Alston, John Tobin and Mac Darrow, 'Laying the Foundation for Children's Rights' in Innocenti Insight no 10 (UNICEF Innocenti Research Centre 2005) 21.

71 Iceland's 5 th and 6 th periodic report (n 25$)$.

$7^{2}$ Iceland's 5 th and 6 th periodic report ( $\left.\mathrm{n} 25\right)$. 
CRC does not have constitutional status in Icelandic law and questions have arisen as to what extent the convention's provisions have direct applicability for individuals.

It is important to carefully consider changing the Constitution in order to strengthen and clarify the rights of children. The rights of children should be framed in a separate section that should as a minimum unequivocally contain all the general principles of the CRC. Directly including article 3(1) of the CRC would underline the standard of the best interests of the child and the need for child rights impact assessments in different contexts. Explicit inclusion of article 12 on the right to participation would further symbolise the status of children as rights-holders.

\section{References}

Aðalsteinsson R, 'Stefnumið eða dómhæf réttindi?' in Ragnheiður Bragadóttir (ed), Afmcelisrit:Jónatan Pórmundsson (Codex 2007).

Árnason ÁP, 'Knowledge that works in practice: Strengthening Nordic co-operation in the social field' (Nordic Council of Ministers 2018).

Alston P, Tobin J and Darrow M, 'Laying the Foundation for Children's Rights' in Innocenti Insight no 10 (UNICEF Innocenti Research Centre 2005).

Bull T, 'Institutions and Division of Powers' in Helle Krunke and Björg Thorarensen (eds), The Nordic Constitutions: A Comparative and Contextual Study (Hart Studies in Comparative Public Law 2018).

Cantwell N, "The Origins, Development and Significance of the United Nations Convention on the Rights of the Child' in Sharon Detrick and others (eds), The United Nations Convention on the Rights of the Child: A Guide to the 'Travaux Préparatoires' (Martinus Nijhoff Publishers 1992).

European Agency for Special Needs and Inclusive Education, Education for All in Iceland - External Audit of the Icelandic System for Inclusive Education (European Agency for Special Needs and Inclusive Education 2017).

Flóvens B, 'The Implementation of the UN Convention and the Development of Economical and Social Rights as Human Rights' in Oddný Mjöll Arnardóttir and Gerard Quinn (eds), UN Convention on the Rights of Persons with Disabilities (Martinus Nijhoff Publishers 2009).

Fortin J, 'Children as Right Holders' in Antonela Invernizzi and Jane Williams (eds), Children and Citizenship (Sage Publications 2008).

Friðriksdóttir H, 'Að nota samning SP um réttindi barnsins með hendi og vendi að hingað til brúkanlegum siðvana' in Rannsóknir í félagsvísindum X (Félagsvísindastofnun Háskóla Íslands 2009). 
Gauksdóttir G, 'The effects of ECHR on the Legal and Political Systems of Member States - Iceland' in Robert Blackburn and Jörg Polakiewicz (eds), Fundamental Rights in Europe; The European Convention on Human Rights and its Member States 1950-2000 (OUP 2000).

Gísladóttir E, 'A Child's Right to Participation in Iceland' in Trude Haugli and others (eds), Children's Constitutional Rights in the Nordic Countries (Brill 2019).

Guðmundsdóttir D, 'Um lögtöku mannréttindasáttmála Evrópu og beitingu í íslenskum rétti' (1994) 44(3) Tímarit lögfrceðinga.

Guðmundsdóttir D, 'Stjórnarskrárbundnar meginreglur og stjórnarskrárvarin réttindi' in Pétur Kr. Hafstein and others (eds), Afmcelisrit Guðrúnar Erlendsdóttur (Hið íslenska bókmenntafélag 2006).

Helgadóttir R, 'Afstaða dómstóla til hlutverks síns við mat á stjórnskipulegu gildi laga próun síđustu ára' (2002) 55(1) Úlfljótur.

Helgadóttir R, 'Próun stjórnarskrárinnar: Stjórnarskrárbreytingar, venjuréttur og framkvæmd frá 1874' in Björg Thorarensen and others (eds), Afmcelisrit Páll Sigurðsson (Codex 2014).

Hodges R and Newell P, Implementation Handbook for the Convention on the Rights of the Child (Unicef 2007).

Iceland's $5^{\text {th }}$ and 6 th periodic report to the Committee on the Rights of the child, November $2018<$ https://www.stjornarradid.is/lisalib/getfile.aspx?itemid=576bca313130-11e9-9431-005056bc4d74> accessed 21 August 2019.

Ombudsman for Children, Helstu áhyggjuefni 2017 [Main Concerns 2017], (2017).

Parliamentary Assembly 1994-95, Document 389 - case 297.

Parliamentary Assembly 2018-2019, Document 156 - case 156.

Ragnarsson KH, 'Dómstólar geta ekki vikið sér undan pví að taka afstöðu: Um vernd efnahagslegra, félagslegra og menningarlegra réttinda fyrir dómstólum' (2009) 62(4) Úlfljótur tímarit laganema.

Ragnarsson KH, 'Falsvonir Öryrkjabandalagsdómsins? - nýleg dómaframkvæmd um félagsleg réttindi' (2017) 70(1) Úlfljótur.

Ragnarsson KH, 'Mannréttindasamningar og túlkun laga: nýlegir dómar í andstæðar áttir' <https://ulfljotur.com/2018/05/17/mannrettindasamningar-og-tulkun-laganylegir-domar-i-andstaedar-attir/> accessed 12 October 2018.

Reynaert D and others, 'Introduction: A critical approach to children's rights' in Wouter Vandenhole and others (eds), Routledge International Handbook on Children's Rights Studies (Routledge 2015).

Smith E, 'Judicial Review of Legislation' in Helle Krunke and Björg Thorarensen (eds), The Nordic Constitutions: A Comparative and Contextual Study (Hart Studies in Comparative Public Law 2018).

Stjórnarskrá lýðveldsins Íslands, No 33/1944. Available in english at <https://www.government.is/constitution/> accessed o1 October 2018. 
Stjórnlagaráð, a Constitutional Council, A Proposal for a new Constitution for the Republic of Iceland < http://www.stjornlagarad.is/other_files/stjornlagarad/Frumvarpenska.pdf $>$ accessed 1 October 2018.

Suksi M, 'Common Roots of Nordic Constitutional Law? Some Observations on Legal-Historical Development and Relations between the Constitutional Systems of Five Nordic Countries' in Helle Krunke and Björg Thorarensen (eds), The Nordic Constitutions: A Comparative and Contextual Study (Hart Studies in Comparative Public Law 2018).

Thorarensen B, 'Mechanisms for Parliamentary Control of the Executive' in Helle Krunke and Björg Thorarensen (eds), The Nordic Constitutions: A Comparative and Contextual Study (Hart Studies in Comparative Public Law 2018).

Thorarensen B, 'Beiting ákvæða um efnahagsleg og félagsleg mannréttindi í stjórnarskrá og alpjóđasamningum' (2001) 51(2) Tímarit lögfræðinga.

Thorarensen B, Stjórnskipunarréttur: Mannréttindi (Codex 2008).

Thorarensen B, 'People's contribution to constitutional changes' in Xenophon Contiades and Alkmene Fotiadou (eds), Participatory Constitutional Change: The People as Amenders of the Constitution (Routledge 2017).

UN Committee on the Rights of the Child, Concluding observations: Iceland (23January 2012) $\mathrm{CRC} / \mathrm{C} / \mathrm{ISL} / \mathrm{CO} / 3-4$.

UN Committee on Civil and Political Rights, General Comment No 17: Article 24 (Rights of the Child) (1 April 1989).

UN Committee on Economic, social and cultural rights, General Comment No 12: The right to adequate food, 1999. UN Doc. HRI/GEN/1/Rev.7(2004).

UN Committee on the Rights of the Child, Day of General Discussion on 'Resources for the rights of the child - Responsibility of states' (21 September 2007).

UN Committee on the Rights of the Child, General Comment No 8: The rights of the child to protection from corporal punishment and other cruel or degrading forms of punishment (arts. 19; 28, para.2; and 37, inter alia) (2 March 2007) CRC/C/GC/8.

UN Committee on the Rights of the Child, General Comment No 17: The rights of the child to rest, leisure, play, recreational activities, cultural life and the arts (ars. 31) (17 April 2013) CRC/C/GC/17.

Verhellen E, 'The Convention of the Rights of the Child: Reflections from a historical, social policy and educational perspective' Wouter Vandenhole, and others (eds), Routledge International Handbook on Children's Rights Studies (Routledge 2015). 